\title{
The Effects of School Culture on Students Academic Achievements
}

\section{OPEN ACCESS}

Manuscript ID:

EDU-2021-09033885

Volume: 9

Issue: 3

Month: June

Year: 2021

P-ISSN: 2320-2653

E-ISSN: 2582-1334

Received: 04.04.2021

Accepted: 20.05.2021

Published: 01.06.2021

Citation:

Bayar, Adem, and Hürriyet Alkan Karaduman. "The Effects of School Culture on Students Academic Achievements." Shanlax International Journal of Education, vol. 9, no. 3, 2021, pp. 99-109.

DOI:

https://doi.org/10.34293/ education.v9i3.3885

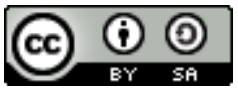

This work is licensed under a Creative Commons Attribution-ShareAlike 4.0 International License

\author{
Adem Bayar \\ Associate Professor, Amasya University College of Education, Amasya, Turkey \\ https://orcid.org/0000-0002-8693-9523
}

\section{Hürriyet Alkan Karaduman}

Teacher, Ministry of National Education, Samsun, Turkey

https://orcid.org/0000-0002-5581-2466

\begin{abstract}
The purpose of this research is to make a detailed examination of the school culture and its effects on the academic achievement of students. In this research that has been carried out within the framework of the qualitative research approach, the answers have been sought to be found to the questions "What is school culture?", "What are the effects of school culture on academic achievement?" and "What should be done at school to create a strong and positive culture?". The study group of this research consists of 12 students determined using a maximum variation sampling technique which is one of the purposeful sampling techniques and studying at a high school within the scope of the Ministry of National Education. Data were collected by a semistructured interview method. The data collected were analyzed by a descriptive analysis technique. The participant students have expressed that the school culture means the behaviors at school, the background and successes of school, circle of friends, school uniforms and social activities.

Moreover, the students have stated that the school culture has effects on the achievement of students in terms of motivation (will to study), sense of competition and their development in all respects. Lastly, the participants have offered some suggestions like the number of social activities should be increased; laboratories should be used actively and improvements should be made at the library in terms of number and contents of books; relations, attitudes and behaviors between teachers and students should be regulated and school trips should be organized concerning the creation of a strong and positive culture at school. In line with the findings, the researchers have concluded that school culture has a positive and strong effect on the academic achievement of students. Therefore, suggestions that would improve the school culture should be put into practice.
\end{abstract}

Keywords: Culture, School culture, Student, Academic achievement, Strong culture, Positive effect

\section{Introduction}

Culture includes all products, institutions, customs and traditions, attitudes and behaviors emerging as a result of the relations and interactions shared among people living in a society; in other words, culture consists of all beliefs and purposes (Başaran, 1994).

According to Çelikten (2006), school culture is composed of all the values, implementations and beliefs shared among people present at school. Balc1 (2011) has stated that traditions coming from the past of the school, knowledge of those who are at school and the reciprocal communication of them with each other play a role in the formation of school culture. School culture is being formed because of the life experiences and sharings among people over time. Attitudes and behaviors of school management, teachers, students, and school staff have contributed to the formation of school culture within this period. There are great differences between schools in terms of the behaviors of students and teachers, being in touch with the parents, conducting social and cultural events, moral conducts that valued, \& communication among people. 
Just as people have their personalities, schools also form their personalities over time (www.hurriyet. com.tr/egitim/basariyi-o-belirliyor-40323848). This personality formed reflects the culture of the school.

According to Demirtaş and Güneş (2002), achievement means all the behaviors that are in line with the objectives of the program. For students to be considered successful, they are required to perform those behaviors. In that case, what is the impact of school culture on the academic achievements of students? Balc1 (2001) stated that people working together at school unite on the matters of what should be considered important at school and what things are expected to be performed at school, and school culture plays a significant role in the emergence of what is expected from teachers and students; and he expressed that in an effective school, above-mentioned school culture promotes the personal growth and self-learning of people; and it is in a structure that supports the education-training activities at school, as well.

Studies are stating that school culture influences the achievement of students have generally been carried out by getting the opinions of teachers. However, the number of studies carried out by getting the opinions of students is quite limited. Therefore, the purpose of this research is to examine the school culture and its effects on the academic achievements of students.

\section{Literature Review}

The matters of culture, school culture, dimensions of school culture, strong and positive school culture and academic achievement have been addressed under this title.

\section{Culture}

When the related literature is examined, it is seen that culture has many definitions. For instance, according to Fitcher (2002), culture is the signs and symbols that differentiate societies from each other. Culture both includes the values of a society and interprets the values in question. There are factors within the culture that form the social solidarity and the culture incorporates the factors that are prevalent for the development and improvement of the society. According to Taylor (1865), culture comprises knowledge, sense of art, manners and customs, skills, and habits that a person has learned in the society s/ he lives (as cited in Güvenç, 1996). Gökalp (1994) stated that culture is a whole in which religious, moral, legal, mental, aesthetic, linguistic, economic, and scientific points of life peculiar to a nation are in harmony with each other. Culture can be defined as a whole of the life experiences transferred from one generation to another.

\section{School Culture}

Most of the studies carried out on school culture have focused on the change and improving a school; they have assumed that understanding the culture of a school is a prerequisite to making them much effective (Deal, 1985; Deal \& Peterson, 1990; transferred: Hoy \& Miskel, 2013; Metz, 1986; Rossman, et al., 1988). According to Özdemir (2012), school culture is a whole of the values, beliefs, and norms peculiar to the school. To understand the culture of a school, symbols, traditions, ceremonies, rites, legends, and stories doing the rounds representing the school may be examined (Hoy \& Miskel, 2013). Culture can be observed when the informal and unwritten relations among people are being investigated (Goldring, 2002). Colley (1999) also considered the school culture as a structure that incorporates various students, teachers, school administration, and parents.

It may be said that values adopted by school for years and attitudes of those working at school, of students receiving an education there and of parents of students in question are effective in the formation of the school culture.

\section{Dimensions of School Culture}

When the studies concerning the dimensions of school culture are examined, it is seen that the culture peculiar to a school has many different dimensions. Accordingly, Craig C. Lundberg (1985) put forward that the school culture consists of at least four dimensions (as cited in Aydın, 2018). The first level includes cultural productions and oral productions. The second level includes the perspectives of people. While the third level includes the school's values, the fourth level includes the assumptions (Aydın, 2018). 
School cultures can be interpreted by analyzing the symbols, events, rites, ceremonies, icons, heroes, myths, traditions, and legends peculiar to the schools (Hoy \& Miskel, 2013). According to Aydın (2018), while identifying the culture of the school, questions such as which traditions have still been followed by the school, whether are there any teachers or students whose characteristics and what they did have still been remembered can be asked to obtain information about the history of the school. Concerning the beliefs of school, though not being stated directly, questions like what assumptions are shared by teachers and other people present at school and how their ways of thinking may be asked. Regarding the values, questions like what the school awards and what things are looked up by the school can be asked. On the matters of norms and standards, behaviors that are awarded and punished may be examined while determining the norms and standards shaping the behaviors at school. Concerning the behavioral patterns, a question like the behavioral patterns, traditions and ceremonies that are approved and repeated by everyone can be asked.

On the matter of realizing the common purposes, the school culture has a leading role, and it forms the norms concerning what things are expected to be accomplished. A school culture comprising common purposes is required to be formed for students to be successful and to continue their success (Sergiovanni, 2001; as cited in Özdemir, 2012).

When the dimensions of school culture are being considered, it can be said that myths, ceremonies, traditions, and events that have been followed and transferred from the school's past to the present are effective.

\section{Strong and Positive School Culture}

The school leader is responsible for forming a strong and positive school culture at school in the first place. School leaders have an important place in forming positive school culture at school by creating a common vision, placing importance on cooperation and a common participation in administration, and having effective communication with the people working at school (Köker \& Yeniçeri, 2013).

According to Gümüşeli (2006), the first thing that a principal should do on school culture is to create a strong school culture. School administration is responsible for the formation and conservation of strong school culture to a large extent. Therefore, the principal should know about what elements are forming the culture and $\mathrm{s} /$ he should define the school in which $\mathrm{s} /$ he is the principal by analyzing the school within that knowledge. Thus, sub-cultures that have destructive effects can not appear in strong school culture.

There are common goals in the schools that have a strong and positive school culture and they are shared among people working there; those who work there are motivated to teach. To appreciate the achievements of students and teachers, some ceremonies are being held. They have become traditional; heroic stories have been doing the rounds unofficially; predetermined criteria are determined by the good works and developments of students (Deal \& Peterson, 1998). Students are much more eager to learn at the schools having a strong school culture (Fyans \& Maehr, 1990; as cited in Köker and Yeniçeri, 2013)

It can be said that strong and positive school culture is formed by the school principal, teachers, and students. It can be expressed that the abovementioned people have close relations with each other on the matter of realizing the common goals of the school.

\section{Academic Achievement}

When the literature is being examined, it is seen that there are many similar definitions concerning achievement and academic achievement. For example, Demirel (2001) defined achievement as having students reach the targets of the program in question sufficiently as a result of the program with which they are provided. Criterion indicating to what extent a student can benefit from the courses at school is defined as achievement (Carter \& Good, 1973; Wolman, 1973; as cited in Aslanargun, et al., 2016).

Having importance placed on academic achievement by the school, having a good teaching staff and teachers' trust in parents and students are the factors that affect the achievement of students; and they are in a close relationship with each other (Hoy, et al., 2006). To increase the level of academic 
achievement, it is effective for schools to determine their academic achievement goals in a clear and unambiguous expression; to explain those goals to students, teachers and instructors; to motivate the people in question for fulfilling such goals; to award the achievement, and to encourage students on the matter of achievement (Köker \& Yeniçeri, 2013). Furthermore, while examining the effectiveness and productivity of the schools, academic achievement is one of the most significant criteria that reflects the schools in this regard (Good \& Brophy, 1986; Harris, 2000).

To reach academic achievement, school administration, teachers and students should be focused on the achievement; should be motivated and willing for the achievement.

\section{The Purpose of Study and Research Questions}

In this study, it is aimed to examine the effects of school culture on the academic achievements of students. In line with this purpose, the answers have been sought to be found to the following questions:

- What is school culture?

- What are the effects of school culture on academic achievement?

- What should be done at school to create a strong and positive culture?

\section{Method}

The subtitles of the research method, research design, study group, roles of researchers and data collection and analysis have been referred to under this part.

\section{Method of Research}

This research has been carried out within the framework of the qualitative research approach. The qualitative research approach is a process that is being followed to explain the perceptions and cases on a matter in a way to reflect the truth in the environments peculiar to them and as a whole by using various data collection techniques such as observation, interview, and document analysis (Yıldırım \& Şimşek, 2008). The qualitative research approach is one of the knowledge generation stages; lifestyles, stories, behaviors of people, organizational structures, and social change have been sought to be understood in this research method (Strauss \& Corbin, 1990). According to Storey (2007), the qualitative research approach aims at learning the subjective points of view of people related to an event. The qualitative research approach is interested in how people perceive the events; in other words, it is interested in describing the events (Dey, 1993). In this research method, the person feels the problem s/he encounters in his/her own life and s/he observes and examines that problem in its natural environment, but $\mathrm{s} /$ he does not intervene in the problem in question. This research method is one of the new information retrieval methods formed by the person to offer an insight into what $\mathrm{s} / \mathrm{he}$ feels and to examine thoroughly the social systems that $\mathrm{s} /$ he contributes to its formation (Özdemir, 2010). The qualitative research approach is based on the assumption that the researcher sets up the reality, there is an interaction with the reality in question, the reality is being comprehended by the researcher's point of view and it is necessary to use personal language in the report concerning the research (Creswell, 1994).

\section{Research Design}

This research has been prepared using phenomenology research design which is one of the research designs of qualitative research. In phenomenological studies, we are aware of a fact, but we do not have a deep and detailed understanding of the fact in question (Cropley, 2002). According to Çepni (2007), objective views and opinions are expressed in the phenomenology design and importance is placed on individual differences. According to Annells (2006), what is aimed in phenomenology design is to show the common practices and define and explain the meanings gathered from the participants. Phenomenology studies aim to increasing the personal experiences on a more general level (Creswell, 2007). These types of studies it is aimed at revealing what the personal perceptions of people on a fact are in general and interpreting such perceptions (Yıldırım \& Şimşek, 2008). Phenomenology research design has sought an answer to the question "What is the truth?" This design consists of personal experiences. The researcher places importance on the person's own experiences and $\mathrm{s} / \mathrm{he}$ examines how the individuals 
perceive a fact and how they attribute a meaning to the events. It is significant to define the facts in the phenomenology research design; it does not have a purpose of generalization (Akturan \& Esen, 2008), they may not present a general result, but the instances, explanations, and experiences collected via this design may help better examination and interpretation of a fact in question (Y1ldirım \& Şimşek, 2013). Answers to two questions have been sought to be found in this method: 1 . What kind of perception is there on a fact and what have people experienced on that fact? and 2. Under what kind of environments and conditions such experiences have been experienced (Creswell, 2013). Therefore, the researchers collected the data using a semi-structured interview technique to determine the views of students who are studying at a high school within the scope of the Ministry of National Education on school culture and the effect of school culture on academic achievement.

\section{Study Group}

The study group of this research consists of 12 students (until reaching the data saturation) who are studying in a high school within the scope of the Ministry of National Education. Students were determined via a maximum variation sampling technique which is one of the purposeful sampling methods. This sampling technique is a nonprobability sampling approach. This approach enables conducting detailed research. This approach is a technique used widely to determine and choose the cases rich in terms of information to use the limited sources in the best effective way (Patton, 2002). In this sampling technique, a case study is trying to be found until there is no variety left related to the case study chosen by the researchers (Neuman, 2007). In addition to the knowledge and experience, it is also important that the participants are available, they are willing, and they can explain their experiences and opinions in a fluent, expressive, and reflective manner (Bernard, 2002; Spradley, 1979). The maximum variation sampling technique is based on reflecting the diversities of individuals affected by the case at the highest level (Yildirım \& Şimşek, 2008). The diversity in this research is ensured by including students from different grades in the research. 3 male and 9 female students took part in the research and their identities were kept secret. The participants were coded S1, S2, S3, .... and S12 in a way that each one represents a different student. Some of the answers given by the students were written in the findings part as citations.

Table 1: Demographic Information related to Participants

\begin{tabular}{|c|c|c|c|}
\hline & & $\mathbf{f}$ & $\mathbf{\%}$ \\
\hline \multirow{3}{*}{ Gender } & Female & 9 & 75 \\
\cline { 2 - 4 } & Male & 3 & 25 \\
\hline \multirow{4}{*}{ Age } & 14 & 3 & 25 \\
\cline { 2 - 4 } & 15 & 3 & 25 \\
\cline { 2 - 4 } & 16 & 3 & 25 \\
\cline { 2 - 4 } & 17 & 3 & 25 \\
\hline \multirow{4}{*}{ Grade } & 9th grade & 3 & 25 \\
\cline { 2 - 4 } & 10 th grade & 3 & 25 \\
\cline { 2 - 4 } & 11 th grade & 3 & 25 \\
\cline { 2 - 4 } & 12th grade & 3 & 25 \\
\hline
\end{tabular}

As seen in Table 1, 9 of the participants are female students and 3 of the participants are male students; they are aged between 14 and 17. Besides, 3 of the participants are studying in the 9th grade; 3 of them are studying in the 10th grade; 3 of them are studying in the 10th grade, and 3 are studying in the 12 th grade.

\section{Role of Researchers}

The first researcher is an educational scientist who has highly believed in the importance of school culture both while he was working as a teacher within the Ministry of National Education and within this period in which he is still working within the scope of Higher Education. In this regard, he decided to carry out this study to draw attention to the importance and necessity of school culture.

The second researcher has been working as a permanent English Teacher for 7 years within the scope of the Ministry of National Education. Within this period, she has found an opportunity to work in two different high schools. She had a chance to observe the school culture and the academic achievement status of students and to be able to ascertain the differences between school cultures and the academic achievements of students. Therefore, 
she decided to carry out this study which is related to the effects of school culture on the academic achievements of students.

\section{Data Collection and Analysis}

In this research, a semi-structured interview technique was used as a data collection tool. This technique presents more systematic and comparable information to the researcher. Because the researcher prepares an interview protocol before the interview and $\mathrm{s} / \mathrm{he}$ sticks to that protocol during the interview; this provides convenience to the researcher (Yıldırım \& Şimşek, 1999). In this technique, interview questions may be prepared by the researcher beforehand. Still, the researcher may change the questions, may change the orders of the questions, or may add additional questions to his/her questions in line with the answers s/he has received (Çepni, 2007). The point to which attention should be paid while preparing the questions is that they should be articulate, and they should not be leading and multidimensional questions (Altunay, et al., 2014). While the questions were being prepared for the research, a literature review was done, the opinion of an expert was received, an interview was done with two students as a pilot interview, and the questions were checked in articulacy. Interview questions were finalized in this way.

Semi-structured interviews were held via the zoom program when the participants (interviewees) are available. Interviews took 25-30 minutes. No leading questions were asked during the interviews. The voices of participants were recorded by getting the consent them and then answers received from them were transferred to the word document without making any changes.
Descriptive analysis technique was used in the analysis of the data collected. In the descriptive analysis, data are received from the people with whom the interviews are done, and they are transferred as quotations without making any changes to them. The researcher can summarize and then interpret the data obtained from the participants using this method. Data can be prepared using the themes obtained from the answers to the questions, or they can be created according to the observation made and interviews held. Experiences of those with whom the interviews were held are indicated by a direct quotation in this type of analysis. In this technique, a framework is created at first; then data are processed according to the thematic framework; after that, the findings are identified and finally, the findings are interpreted (Yıldırım \& Şimşek, 2013). Descriptive analysis is performed in four stages by creating a framework, processing data according to the framework in question, identifying the findings, and finally interpreting the findings obtained (Altunışık, et al., 2010). Researchers adopt the descriptive analysis method when they intend to get summary knowledge about the facts or events on which they would like to study (Büyüköztürk, et al., 2008).

\section{Findings and Interpretation}

Findings obtained in this research are explained according to the research questions. The first question of this research was "What is school culture?". When the answers given by students to this question were analyzed, it was seen that the participants expressed that the school culture is formed together with the behaviors at school, history and achievements of the school, circle of friends, school uniforms, and social activities. Related findings were indicated in the table below.

Table 2: Perceptions about School Culture

\begin{tabular}{|l|l|l|l|}
\hline \multicolumn{1}{|c|}{ Theme } & f & \% & \multicolumn{1}{c|}{ Example sentence } \\
\hline $\begin{array}{l}\text { Behaviors at } \\
\text { school }\end{array}$ & 4 & 31 & $\begin{array}{l}\text { "Relationships established, decisions made together or visual, auditory indicators at } \\
\text { school form the school culture." (S1) } \\
\text { "When you say school culture, it reminds me of communication and interaction rules } \\
\text { within the framework of respect and the behaviors, as well." (S8) }\end{array}$ \\
\hline $\begin{array}{l}\text { History and } \\
\text { achievements of } \\
\text { the school }\end{array}$ & 3 & 24 & $\begin{array}{l}\text { "It reminds me of the history, traditions, customs, achievements of the school." (S5) } \\
\text { "When we speak of school culture, it reminds me of the background, history and } \\
\text { achievements of the school." (S2) }\end{array}$ \\
\hline
\end{tabular}




\begin{tabular}{|c|c|c|l|}
\hline Circle of friends & 2 & 15 & $\begin{array}{l}\text { "School culture is our relationship with our circle of friends, our good manners } \\
\text { towards our teachers, our behaviors that we display there; these are our school } \\
\text { culture." (S12) }\end{array}$ \\
\hline School uniforms & 2 & 15 & $\begin{array}{l}\text { "When you say school culture, it is our school uniforms, our behaviors I mean our } \\
\text { positive behaviors at school." (S7) } \\
\text { "It is the uniforms of school, rules of school, our respect towards our teachers when } \\
\text { we are at school, courses." (S9) }\end{array}$ \\
\hline Social activities & 2 & 15 & $\begin{array}{l}\text { "Administration, teachers and my classmates, my school friends, activities, social } \\
\text { activities conducted at school and courses." (S3) } \\
\text { "I think when we speak of school culture, it reminds me of a school that is the most } \\
\text { successful one among other schools or that is open to competitions, activities." (S4) }\end{array}$ \\
\hline Total & 13 & 100 & \\
\hline
\end{tabular}

As seen in Table 2, 31\% of the students think that school culture is composed of the behaviors at school, $24 \%$ of them think that history and achievements of the school form the school culture, $15 \%$ of the state that circle of friends forms the school culture, $15 \%$ of the state that school uniforms form the school culture, and $15 \%$ of the state that school culture is formed by the social activities.
The second question of the research was "What are the effects of school culture on academic achievement?". When the answers received from the participants were analyzed, it is found out that it has effects in terms of 1) motivation (will to study), 2) sense of competition, and 3) development in all respects, respectively.

Table 3: Effects of School Culture on the Academic Achievement

\begin{tabular}{|l|c|c|l|}
\hline \multicolumn{1}{|c|}{ Theme } & f & $\mathbf{\%}$ & \multicolumn{1}{c|}{ Example Sentence } \\
\hline $\begin{array}{l}\text { Motivation (will to } \\
\text { study) }\end{array}$ & 5 & 42 & $\begin{array}{l}\text { "Because there are hardworking students in our school and I always have to } \\
\text { be ahead of those who are at my level. This motivates me to study." (S11) }\end{array}$ \\
\hline Sense of competition & 5 & 42 & $\begin{array}{l}\text { "There is a competitive environment. When we see a single student } \\
\text { studying, it also affects us. We also have to study." (S7) }\end{array}$ \\
\hline $\begin{array}{l}\text { Development in all } \\
\text { respects }\end{array}$ & 2 & 16 & $\begin{array}{l}\text { "There are tennis tournaments being organized and I am a person who plays } \\
\text { tennis well. This enables me to increase my dominance at sports and in this } \\
\text { way my hobby is also being created." (S11) }\end{array}$ \\
\hline Total & 12 & 100 & \\
\hline
\end{tabular}

As it is seen in Table 3, 42\% of the students state that school culture affects their academic achievements by creating a will to study for them; $42 \%$ of them state that the school culture creates a sense of competition for them, and $16 \%$ of the state that the school culture increases their academic achievements by contributing to the developments in all respects.

On the matter that school culture affects academic achievement by creating a will to study, one of the students expressed that "... people around me I mean people at school already have potential and we already know that they study. Because of this, when I see that they study, frankly speaking, I also get motivated to study" (S2).

In the way of supporting this statement, another student stated that:

"We are new at school now but in my new circle of friends every one of the student's studies and when I see them study, I tell myself that they can do it if they can do it, I also have to do it. Because a person gets this opinion, this creates much more will to study. I appreciate their achievements, but I also want to succeed after I see their achievements. Therefore, this situation creates much more eagerness to study for a person." (S10)

One of the students expressed his/her idea about the change in academic achievements of students by the creation of a sense of competition by the school culture as follows:

"At our school, we have both good friends and friends with whom we can compete. This situation creates a 
sense of excitement. It magnificently creates a feeling like you can be like them by studying. I think of my rivals in other cities in Turkey and I want to study more." (S12).

On the matter of competition, the other students made a statement as follows:

"All in all, we will all take an exam. For example, everybody studies and if I see myself not studying, I mean if I am not studying while everyone is studying, that will make me uncomfortable. As we talk about the achievement and as our school is a very successful school with its students, I have been affected many times like I also should study, I should do better." (S5)

On the matter of contribution of school culture to the academic achievement by ensuring development in all respects, one of the students stated that:
"For instance, when I was at secondary school, I wanted to play table tennis so much, but there weren't too many tennis tables. However, I can play tennis, I mean table tennis, at high school thanks to both my physical education teacher and the existence of all tools at our school that I need for playing it. This has been effective in my development. My reflexes become much better." (S8)

The third and last research question of the research is "What should be done at school to create a strong and positive culture?". When the data concerning this question were analyzed, the participants offered some suggestions like 1) the number of social activities should be increased, 2) laboratories should be used actively and improvements should be made at the library in terms of number and contents of books, 3) relations, attitudes and behaviors between teachers and students should be regulated, and 4) school trips should be organized.

Table 4: Suggestions to Create a Strong and Positive Culture at School

\begin{tabular}{|l|c|c|l|}
\hline \multicolumn{1}{|c|}{ Theme } & $\mathbf{f}$ & $\mathbf{\%}$ & \multicolumn{1}{c|}{ Example Sentence } \\
\hline Social activities & 7 & 32 & $\begin{array}{l}\text { "I think the number of activities may be increased. For example, when } \\
\text { students get tired of the lessons, a different activity may be organized at least } \\
\text { monthly for the students." (S2) }\end{array}$ \\
\hline Laboratory- Library & 6 & 27 & $\begin{array}{l}\text { "For example; if we had a really actively used laboratory, if we did } \\
\text { experiments there, it would be really good. We have enough number of } \\
\text { books at our library, but the number of books may also be increased." (S12) }\end{array}$ \\
\hline $\begin{array}{l}\text { Relations, attitudes } \\
\text { \& behaviors between } \\
\text { teachers and students }\end{array}$ & 5 & 23 & $\begin{array}{l}\text { "I think the attitudes of teachers and students enhance the school culture. As } \\
\text { the school culture enhances, perspective on school and the academic lives of } \\
\text { students will also move forward." (S4) }\end{array}$ \\
\hline School trips & 4 & 18 & $\begin{array}{l}\text { "For instance; Erasmus+ project is being executes and students are brought } \\
\text { to abroad but there are many cities in Turkey that students haven't visited } \\
\text { yet. I think those cities should also be visited much more than the trips that } \\
\text { have been made to the abroad." (S11) }\end{array}$ \\
\hline Total & 22 & 100 & \\
\hline
\end{tabular}

When Table 4 is examined, $32 \%$ of students think that to create a strong and positive culture at school, the number of social activities should be increased; $27 \%$ of them think that laboratories should be used actively and improvements should be made at the library in terms of number and contents of books; $23 \%$ of them think that relations, attitudes and behaviors between teachers and students should be regulated; and $18 \%$ of them think that school trips should be organized both inland and abroad.

One of the students expressed his/her idea on increasing the number of social activities to create a strong and positive culture at school as follows: "We may have more school activities. We will do sports, play volleyball and football; they may be a load off our mind, after all. The number of games played at festivals may be increased." (S7)

Likewise, another student made the following explanation:

"The student both has time for studying and time for relaxing. I mean there are lots of students at our school who study hard; the number of students is high 
and students need to blow off some steam. Therefore, having activities, tournaments held in school may be effective in forming the school's culture." (S10)

On the matter of more active use of laboratories and the necessity for improving the library to create a strong and positive school culture at school, one of the students stated that:

"I think a library is like home at schools. It may sound ridiculous, but I think like that. Because we feel relaxed at our home or find everything we search for at our homes like at home, we need to go to the library to find a source or reach something else. I mean, I prefer a library which is upgraded or a library in which there are many resources because I think this affects the school culture." (S5)

Similarly, another student suggested that laboratories should be used more actively and improvements should be made at the library in terms of number and contents of books to create a strong and positive school culture by stating that:

"At the same time, laboratories at school help students to have abstract expressions that they have learned at lessons become concrete. I mean experimenting at a laboratory on the things that the teacher has taught at physics or chemistry lessons lead to permanent learning by giving concrete examples of such things". (S10).

On the necessity of regulating the relations, attitudes and behaviors between teachers and students in the formation of school culture, one of the students stated that:

"I think I can do something to regulate the history or to be more accurate planning a future in the future. If we regulated the relationships between teachers and students in a more sincere and better way, it would create a more respectful society. I mean, I would like to have a school full of respectful students because this also affects the school culture". (S5)

In furtherance of the above-mentioned statement, another student made the following explanation:

"Trips organized within a project to abroad they are all positive things. For example, to have a more effective culture, things like this may be organized apart from the lessons. I think having activities organized in which we can find ourselves would be excellent. For instance, we spend five days a week at school. Maybe we may have lessons for a half-day on Wednesday and we may spend the rest of Wednesday by spending time with teachers by engaging in activities with them." (S9)

On the matter of organizing trips to create a strong and positive culture at school, one of the students stated that:

"Competitions, activities, events and relations with other schools and activities both organized inland and abroad mean too much to me in terms of the formation of a strong and positive culture at my school. If the number of such events is high, I will say that there is positive and strong activeness I mean culture at that school". (S4)

\section{Discussion, Conclusion and Recommendations}

When the findings obtained in this research are compared with some studies carried out on the relevant literature, it is seen that there are some similarities. For example, Erdem and İşbaşı (2001) mentioned in their study what Stolp (1995) had stated that if a school culture has strong traditions, rituals, and ceremonies and if it is embraced deeply, such a school culture affects the achievement and motivation of students and the productivity and satisfaction of teachers in a positive way. It is also observed in this research that school culture plays an important role in the academic achievement and motivations of students.

Yavuz \& Y1lmaz (2012) emphasized the necessity of having activities organized by the school principals at their schools that will create a sense of unity and solidarity to form a positive culture. Likewise, Wren (1999) stated in his study that studies and activities performed by students during the academic year are the significant factors affecting the school culture. It is also seen in this research that students are affected positively by the activities organized at school.

Çubukçu and Girmen (2006) mentioned in their study that the most valuable purpose of the school is to raise people who take pleasure in living. It could be possible by organizing and conducting activities prepared by having considered both social and physical developments of students. In this research that was carried out with students, it is observed that students feel a positive and strong culture at school by sports activities physically. 
In conclusion, for students, the school culture means school, previous and present achievements of the school, circle of friends, school uniforms and social activities. Culture at school has importance on the academic achievement of students in terms of motivation, sense of competition and development in all respects, both social and physical. Students expressed that the above-mentioned factors affect their academic achievements in a positive way. When the literature related to school culture, positive and strong school culture and academic achievement are examined, it is seen that similar results have also been obtained in other studies carried out in such fields. It can be said literally in this research that the culture of a school is effective on the academic achievements of students at the school in question. Researchers suggest the following recommendations on the formation of positive and strong school culture at school from the points of views of students:

- The number of extracurricular activities for students should be increased at school.

- Importance should be placed on the planning and performing social activities and organizing trips.

- Laboratories at school should be used more actively and students should be provided with an opportunity to express themselves there.

- The number of books should be increased at the library.

- Relations, attitudes and behaviors between teachers and students should be pre-arranged and their relations should continue in this order.

\section{References}

Akturan, Ulun, and Atakan Esen. "Fenomoneloji." Nitel Araştırma Yöntemleri. Seçkin Yayıncilik, 2008.

Altunay, Esen, et al. "A Qualitative Research About Mobbing Implications in Educational Institutions." Sakarya University Journal of Education, vol. 4, no. 1, 2014, pp. 62-80.

Annels, Merrilyn. "Triangulation of Qualitative Approaches: Hermeneutical Phenomenology and Grounded Theory." Journal of Advanced Nursing, vol. 56, no. 1, 2006, pp. 55-61.

Aslanargun, Engin, et al. "The Impacts of Socioeconomic Variables on the Academic Success of the Students." Uşak Üniversitesi
Sosyal Bilimler Dergisi, vol. 9, no. 3, 2016, pp. 214-234.

Aydın, Mustafa. Eğitim Yönetimi. Gazi Kitabevi, 2018.

Balc1, Ali. Etkili Okul: Okul Geliştirme, Kuram Uygulama ve Araştırma. Pegem A Yayıncılık, 2011.

Başaran, İbrahim Ethem. Eğitime Bilimine Giriş. Pegem A Yayıncılık, 1994.

Bernard, H. Russel. Research Methods in Anthropology: Qualitative and Quantitative Approaches. Alta Mira Press, 2002.

Büyüköztürk, Şener, et al. Bilimsel Araştırma Yöntemleri. Pegem Akademi, 2008.

Çelikten, Mustafa. "Culture and Teacher Metaphors Used in Educational System." Sosyal Bilimler Enstitüsü Dergisi, no. 21, 2006, pp. 269-283.

Çepni, Salih. Araştırma ve Proje Çalışmalarına Giriş. Pegem Akademi Yayıncılık, 2007.

Colley, Kenna M. Coming to Know a School Culture. Virginia Polytechnic Institute and State University, 1999.

Coşkun, Recai, et al. Sosyal Bilimlerde Araştırma Yöntemleri. Sakarya Kitabevi, 2010.

Creswell, John W. Qualitative Inquiry \& Research Design: Choosing among Five Approaches. SAGE Publications, 2007.

Creswell, John W. Research Design: Qualitative and Quantitative Approaches. SAGE, 1994.

Çubukçu, Zühal and Pınar Girmen. "Levels of Effectiveness Characteristics in Secondary Schools." Sosyal Bilimler Dergisi, no. 16, 2006, pp. 121-136.

Deal, Terrence E., and Kent D. Peterson. The Principal's Role in Shaping School Culture. U.S. Department of Education, 1990.

Deal, Terrence E. "The Symbolism of Effective Schools." Elementary School Journal, vol. 85, no. 5, 1985, pp. 601-620.

Demirel, Özcan. Eğitim Sözlüğü. Pegem A Yayınc1l1k, 2001.

Demirtaş, Hasan, and Hasan Güneş. Eğitim Yönetimi ve Denetimi Sözlüğ̈̈. Anı Yayıncılık, 2002.

Dey, Ian. Qualitative Data Analysis: A User-Friendly Guide for Social Scientists. Routledge, 1993.

Doğan, Soner. "Evaluation of the School Culture According to the Academicians' Opinions." 
Ĕ̈itim Fakültesi Dergisi, vol. 27, no. 1, 2014, pp. 207-230.

Doğan, Soner. "Okul Kültürü ve İklimi.” Okul Yönetimi. Anı Yayıncılık, 2017, pp. 91-119.

Erdem, Ferda, and Janset Özen İşbaşı. " Organizational Culture in Educational Institutions and the Perceptions of Student Subculture." Akdeniz Üniversitesi İ.I.B.F Dergisi, 2001, pp. 33-57.

Fichter, Joseph. Sosyoloji Nedir? translated by Nilgün Çelebi, Anı Yayıncılık, 2002.

Goldring, Leslie. "The Power of School Culture." Leadership, vol. 32, no. 2, 2002, pp. 32-35.

Good, Thomas L., and Brophy Jere. "School Effects." Handbook of Research on Teaching. Edited by M.C. Wittrock, Macmillan, 1986.

Gökalp, Ziya. Türkçülüğün Esasları, İnkilap Yayınları, 1994.

Gümüş̧eli, A. "Okul Kültürü ve Liderlik.” Artı Eğitim Dergisi, vol. 8, 2006.

Güvenç, Bozkurt. Insan ve Kültür. Remzi Yay, 1996. Harris, Alma. "What Works in School improvement? Lessons from the Field and Future Directions." Educational Research, vol. 42, no. 1, 2000.

Hoy, Wayne, and Cecil G. Miskel. Educational Administration: Theory, Research and Practice. The McGraw-Hill Education, 2013.

Hoy, Wayne K., et al. "Academic Optimism of Schools: A Force for Student Achievement." American Educational Research Journal, vol. 43, no. 3, 2006, pp. 425-446.

Korkut, Adem, and Özge Hacıfazlığlu. "Teachers Perceptions of School Culture: Buyukcekmece Sample." Electronic Journal of Social Sciences, vol. 10, no. 37, 2006, pp. 135-152.

Metz, Mary Haywood. Different by Design: The Context and Character of Three Magnet Schools. Teachers College Press, 1986.

Özdemir, Murat. "Qualitative Data Analysis: A Study on Methodology Problem in Social Sciences.” Eskişehir Osmangazi Üniversitesi
Sosyal Bilimler Dergisi, vol. 11, no. 1, 2010, pp. 323-343.

Özdemir, Servet. "The Relationship between School Culture and Organizational Health in Primary Schools." Educational Administration: Theory and Practice, vol. 18, no. 4, 2012.

Rossman, Gretchen B., etal. Change and Effectiveness in Schools: A Cultural Perspective. State University of New York Press, 1988.

Spradley, James P. The Ethnographic Interview. Holt, Rinehart \& Winston, 1979.

Stolp, Stephen. Leadership for School Culture. ERIC Clearinghouse on Educational Management, 1994.

Stolp, Stephen. Transforming School Culture. Eric Clearinghouse on Education Management, 1995.

Storey, Lesley. "Doing Interpretative Phenomenological Analysis." Analysing Qualitative Data in Psychology. Edited by E. Lyons, and Adrian Coyle, SAGE, 2007.

Strauss, Anselm, and Juliet Corbin. Basics of Qualitative Research: Grounded Theory Procedures and Techniques. SAGE, 1990.

Wren, David J. "School Culture: Exploring the Hidden Curriculum." Adolescence, vol. 34, 1999, pp. 593-596.

Yavuz, Yaşar, and Emel Yılmaz. "Teacher and Students' Views about School Culture of the State and Private Primary Schools." International Journal of New Trends in Arts, Sports \& Science Education, vol. 1, 2012.

Yeniçeri Alemdar, Mine, and Nahit E. Köker. "Öğrencilerin Okul Kültürü Algısı Üzerine Ampirik Bir Araştırma: Ege Üniversitesi İletişim Fakültesi Örneği." Global Media Journal, vol. 3, 2013, pp. 230-261.

Yıldırım, Ali, and Şimşek Hasan. Sosyal Bilimlerde Nitel Araştırma Yöntemleri. Seçkin Yayıncılık, 2008.

\section{Author Details}

Dr. Adem Bayar, Associate Professor, Amasya University, Amasya, Turkey, Email ID: adembayar80@gmail.com.

Hürriyet Alkan Karaduman, Teacher, Ministry of National Education, Samsun, Turkey,

Email ID: hurriyet35alkan@gmail.com 